\title{
Time Course of Starch Biosynthesis Enzymes Activity and Root Tuber Starch of Four Cassava Cultivars
}

\author{
Huifang Huang, Yanchun Luo, Qiang Huang, Yinong Tian, \& Huimin Li \\ Guangxi Cassava Research Institute, Nanning, China \\ Guangxi Sub-tropic Crops Research Institute, Nanning, China
}

\author{
Xuewen Hou (Corresponding author) \\ Research Center of Plant Stress Biology, College of Life Sciences \\ South-China Agricultural University, Guangzhou, China \\ Tel: 86-20-8528-0194_E-mail: hxw1969@scau.edu.cn
}

Received: November 16, 2016 Accepted: February 12, 2017 Published: February 24, 2017

doi:10.5296/jas.v5i1.10810

URL: https://doi.org/10.5296/jas.v5i1.10810

\begin{abstract}
To understand the accumulation rule of cassava root tuber starch, the amylose, amylopectin and total starch content of fresh root tuber, the enzyme activities of sucrose synthase (SuS, EC 2.4.1.13) and sucrose phosphate synthase (SPS, EC 2.4.1.14) of leaves, the enzyme activities of ADP-glucose pyrophosphorylase (AGPase, EC 2.7.7.27), soluble starch synthase (SSS, EC 2.4.1.21) and starch branching enzyme (SBE, EC. 2.4.1.18) of tubers were assessed by using cultivars SC201, SC205, GR891 and GR911 leaves and root tubers during their growth period, respectively. The results as follows: the enzyme activity of leaf SPS and the synthesis direction of SuS showed the highest at August, 2010, however the enzyme activity of the decomposing direction of SuS formed parabolic curve; the enzyme activity of tuber AGPase showed an increased then decreased single peak curve, the enzyme activity of tuber SSS oscillating decreased, while the enzyme activity of SBE was relatively stable; the amylose, amylopectin and total starch contents of fresh cassava tuber were all gradually increased along with the growth period. This research would enrich our knowledge of the time course of amylose, amylopectin and total starch contents of fresh cassava tuber, and above related enzyme activities.
\end{abstract}

Keywords: ADP-glucose pyrophosphorylase, Cassava starch, Soluble starch synthase, Starch branching enzyme, Sucrose synthase, Sucrose phosphate synthase 


\section{Introduction}

Cassava (Manihot esculent Crantz) was originally from Amazon tropical area, now is planted widely in more than 100 countries. Due to its large amount starch production, it is referred as granary of underground and king of starch (Balagopalan, 2002). The cassava starch has not only widely used as food (Cook and Cock, 1989), raw material for chemical industry (Pimentel et al., 2007), and also as the raw material of biomass energy (Osei et al., 2013). Therefor cassava tuber starch has attracted more and more attention. Systemic research on the accumulation rule of cassava root tuber starch, the activities of starch biosyntheses related enzymes of cassava, and the relationship between starch accumulation and related enzymes activities are necessitated. However, knowledge about this is inferior to other starch crops, such as rice, wheat, maize and potato (Wang and Wang, 2004; Tan et al., 2009). This knowledge will help to screen better cassava cultivars, and to regulate its starch accumulation and enzyme activity through suitable cultivation methods, and also to breed cultivars for higher starch production or starch composition optimized transgenic lines through regulating related enzyme activity by genetic modification (Carvalho et al., 2004; Ihemere et al., 2006). SC201, SC205, GR891 and GR911 are the four cassava cultivars widely planted in Guangxi nowadays. In this research, the root tuber starch content, the enzyme activities of leaf SuS and SPS, tuber AGPase, SSS and SBE were determined by using cultivars SC201, SC205, GR891 and GR911 root tubers as materials during their growth period.

\section{Materials and methods}

\subsection{Materials and Management}

Cassava cultivars SC201, SC205, GR891 and GR911 were cultivated in the experimental field (Red soil, moderate fertility) of Guangxi Sub-tropic Crops Research Institute, Nanning during March 9, 2010, row spacing $1 \times 0.8 \mathrm{~m}$, each block $7 \times 11$ plants, 3 trials randomized block design. Base manure: cassava starch residue $3 \mathrm{t} / \mathrm{ha}$, cassava specific fertilizer 1250 $\mathrm{kg} / \mathrm{ha}$, topdressing $\mathrm{KCl} 450 \mathrm{~kg} / \mathrm{ha}$. Other field management was same as cassava field management (Pan et al, 2014).

\subsection{The Collection of Experiment Materials}

The cassava leaves and tuber materials were collected at July 9, August 10, September 8, October 9, November 8 and December 10 at one month interval, respectively. 1 plant was randomly picked from 1 block, 3 leaves and 3 representative root tubers were chosen, and surface cleaned. Samples were ground to powder with liquid nitrogen, and stored in $-80^{\circ} \mathrm{C}$ for enzyme activity determination.

Sampling for starch assay: 1 plant was picked from 1 block, 3 representative root tubers were chosen, washed and surface dried. Sampled $100 \mathrm{~g}$ from middle of the tuber, enzyme inactivated at $105{ }^{\circ} \mathrm{C}$ for $15 \mathrm{~min}$, then $75^{\circ} \mathrm{C} 24 \mathrm{~h}$ to constant weight. The ratio of dry weight to fresh weight marked as dry material content. Sample was powdered after weighting, and passed through 60 mesh sieves, fat extracted by Soxhlet's fat extraction apparatus 6h, then baked at $80{ }^{\circ} \mathrm{C} 2 \mathrm{~h}$ in baking oven, stored in desiccator for starch determination. 


\subsection{The Extraction of Cassava Leaves Crude Enzymes}

About $1 \mathrm{~g}$ cassava leaf powder were ground with 3mL extraction buffer $(\mathrm{pH} 7.2100 \mathrm{mmol} / \mathrm{L}$ Tris-HCl, $10 \mathrm{mmol} / \mathrm{L} \mathrm{MgCl}_{2}, 1 \mathrm{mmol} / \mathrm{L} \mathrm{Na} \mathrm{NDDT}_{2}$, $10 \mathrm{mmol} / \mathrm{L} \beta$-mercaptoethanol, $2 \%$ ethylene glycol, $1 \%$ PVP (Polyvinylpyrrolidone)) in mortar, then washed twice each with 1 $\mathrm{mL}$ extraction buffer, then collected into centrifuge tube, centrifuged $12000 \mathrm{rpm} 15 \mathrm{~min}$ at $4{ }^{\circ} \mathrm{C}, 2.5 \mathrm{~mL}$ supernatant was taken into dialysis tube, dialyzed in $200 \mathrm{~mL}$ dialysis buffer $(20$ $\mathrm{mmol} / \mathrm{L}, \quad \mathrm{pH} 7.2$ Tris-HCl, $2.5 \mathrm{mmol} / \mathrm{L} \mathrm{MgCl}_{2}, 1 \mathrm{mmol} / \mathrm{L} \mathrm{Na}_{2}$ EDTA, $5 \mathrm{mmol} / \mathrm{L}$ $\beta$-mercaptoethanol, $1 \%$ ethylene glycol) at $4{ }^{\circ} \mathrm{C} 12 \mathrm{~h}$, new dialysis buffer changed at $6 \mathrm{~h}$ once. After dialysis, the volume of the enzyme extract was measured and used as crude enzyme for leaf SuS and SPS assay.

\subsection{The Determination of Enzyme Activity of Cassava Leaves SuS Synthesis Direction}

The method used here was modified from Yu (1999). Each assay using 4 tubes, 1 as control, other 3 are assay repeats, control added with $0.2 \mathrm{~mL} \mathrm{NaOH}$, assay tubes added with $0.2 \mathrm{~mL}$ above crude enzyme extract, then all 4 tubes were added with reaction solution $(100 \mathrm{mmol} / \mathrm{L}$ $\mathrm{pH} 7.2$ Tris- $\mathrm{HCl}, 10 \mathrm{mmol} / \mathrm{L} \mathrm{MgCl}_{2}, 5 \mathrm{mmol} / \mathrm{L}$ UDPG (Uridine diphosphate glucose), 10 $\mathrm{mmol} / \mathrm{L} \mathrm{D}$-fructose), incubating in $30{ }^{\circ} \mathrm{C}$ water bath to react upto $30 \mathrm{~min}$, then the reaction was stopped at boiling water bath for $5 \mathrm{~min}, 0.2 \mathrm{~mL} 2 \mathrm{~mol} / \mathrm{L} \mathrm{NaOH}$ added and mixed, incubated in boiling water bath $10 \mathrm{~min}$ again, $1 \mathrm{~mL}$ of $0.1 \%$ m-dihydroxybenzene and $3.5 \mathrm{~mL}$ $30 \% \mathrm{HCl}$ were added in after cooling down. Mixture was incubated in $80{ }^{\circ} \mathrm{C}$ water bath for $10 \mathrm{~min}, \mathrm{OD} 480 \mathrm{~nm}$ was measured after cooling down. Enzyme activity was calculated as $\mu \mathrm{mol}$ sucrose/gFW·h.

\subsection{The Determination of Enzyme Activity of Cassava Leaves SuS Decomposing Direction}

The method used here was modified from Zhao (2003). Each assay using 4 tubes, 1 as control, other 3 are assay repeats, control added with $0.2 \mathrm{~mL} 2 \mathrm{~mol} / \mathrm{L} \mathrm{NaOH}$, assay tubes added with $0.2 \mathrm{~mL}$ above crude enzyme extract, then all 4 tubes were added $0.4 \mathrm{~mL}$ reaction solution (100 mmol/L pH 7.2 Tris-HCl , 10 mmol/L MgCl 2,5 mmol/L UDP (Uridine diphosphate), 50 $\mathrm{mmol} / \mathrm{L}$ sucrose), incubated in water bath at $30{ }^{\circ} \mathrm{C}$ to reaction for $30 \mathrm{~min}$. The reaction was stopped in boiling water bath for $5 \mathrm{~min}$, then $0.2 \mathrm{~mL} 2 \mathrm{~mol} / \mathrm{L} \mathrm{NaOH}$ added and mixed, 0.5 $\mathrm{mL}$ dinitrosalicylic acid reagent was added, then incubating in boiling water bath for $5 \mathrm{~min}, 4$ $\mathrm{mL}$ distilled water were added in after cooling down, colorimetric analysis at $540 \mathrm{~nm}$. Enzyme activity was calculated as $\mu \mathrm{mol}$ glucose $/ \mathrm{gFW} \cdot \mathrm{h}$.

\subsection{The Determination of Enzyme Activity of Cassava Leaves SPS}

The method used here was modified from Yu (1999). Each assay using 4 tubes, 1 as control, other 3 are assay repeat, control added with $0.2 \mathrm{~mL} 2 \mathrm{~mol} / \mathrm{L} \mathrm{NaOH}$, assay tubes added with $0.2 \mathrm{~mL}$ above crude enzyme extract, then all 4 tubes were added with reaction solution(100 $\mathrm{mmol} / \mathrm{L} \mathrm{pH} 7.2$ Tris-HCl, $10 \mathrm{mmol} / \mathrm{L} \mathrm{MgCl}_{2}, 5 \mathrm{mmol} / \mathrm{L}$ UDPG, $10 \mathrm{mmol} / \mathrm{L}$ 6-P-fructose), incubate in $30{ }^{\circ} \mathrm{C}$ water bath for $30 \mathrm{~min}$, then reaction was stopped in boiling water bath for 5 min, $0.2 \mathrm{~mL} 2 \mathrm{~mol} / \mathrm{L} \mathrm{NaOH}$ was added and mixed, treated in boiling water bath for $10 \mathrm{~min}$ again, $1 \mathrm{~mL} 0.1 \% \mathrm{~m}$-dihydroxybenzene and $3.5 \mathrm{~mL} 30 \% \mathrm{HCl}$ were added in after cooling down. Mixed and incubated in $80^{\circ} \mathrm{C}$ water bath for $10 \mathrm{~min}$, OD480 $\mathrm{nm}$ was measured after 
cooling down. Enzyme activity was calculated as $\mu \mathrm{mol}$ sucrose $/ \mathrm{gFW} \cdot \mathrm{h}$.

\subsection{The Extraction of Cassava Tuber Crude Enzyme}

About 1.0 g cassava tuber powder was added with $3 \mathrm{~mL}$ extraction buffer [100 mM HEPES (Hydroxyethyl piperazine ethanesulfonic acid, $\mathrm{pH} 7.5$ ), $5 \mathrm{mM} \mathrm{MgC1} 1_{2}, 5 \mathrm{mM} \mathrm{DTT}, 2 \%(\mathrm{w} / \mathrm{v}$ ) PVP], ground in pre-cooled mortar, extracted at $4{ }^{\circ} \mathrm{C}$ for $30 \mathrm{~min}$, centrifuged at $4{ }^{\circ} \mathrm{C} 10000 \mathrm{~g}$ $15 \mathrm{~min}$, the supernatant was used for enzyme activity assay.

\subsection{The Determination of Enzyme Activity of Cassava Root Tuber AGPase}

The method of OU-Lee and Setter (1985) was followed. $225 \mu \mathrm{L}$ reaction buffer A [100 mM HEPES-NaOH (pH 7.4), $1.2 \mathrm{mM}$ ADPG (Adenosine diphosphate glucose), $3 \mathrm{mM} \mathrm{Na} 2 \mathrm{PPi}$, $5 \mathrm{mM} \mathrm{MgC1} 1_{2}, 4 \mathrm{mM}$ DTT (Dithiothreitol)] and $100 \mu \mathrm{L}$ above crude enzyme were mixed together, incubate in $30{ }^{\circ} \mathrm{C}$ water bath to react $20 \mathrm{~min}$, the reaction was stopped at boiling water bath for 30 seconds, centrifuged $5 \mathrm{~min}$ at $10000 \mathrm{~g}, 250 \mu \mathrm{L}$ supernatant was added into $750 \mu \mathrm{L}$ reaction buffer $\mathrm{B}\left[100 \mathrm{mM} \operatorname{HEPES}\left(\mathrm{p}\right.\right.$ H7.5), $6 \mathrm{mmol} / \mathrm{L} \mathrm{NADP}^{+}, 1.5 \mathrm{IU} / \mathrm{mL}$ glucophosphomutase, $5 \mathrm{IU} / \mathrm{mL}$ glucose 6-phosphate dehydrogenase], mixed and incubated in $30{ }^{\circ} \mathrm{C}$ water bath to react $10 \mathrm{~min}$, colorimetric analysis at $340 \mathrm{~nm}$. The NADH content was calculated by the molar extinction coefficient (6220) of NADH at $340 \mathrm{~nm}$.

\subsection{The Determination of Enzyme Activity of Cassava Root Tuber SSS}

The method used by Nakamura et al. (1989) was adopted. $180 \mu \mathrm{L}$ reaction buffer A [50 mM HEPES-NaOH(pH 7.4), $1.6 \mathrm{mM}$ ADPG, $0.7 \mathrm{mg}$ amylopectin, $15 \mathrm{mM}$ DTT] and $100 \mu \mathrm{L}$ above crude enzyme were mixed together, incubate in $30{ }^{\circ} \mathrm{C}$ water bath to react $20 \mathrm{~min}$, the reaction was stopped at boiling water bath for $5 \mathrm{~min}$. After cooling down, $100 \mu \mathrm{L}$ reaction buffer B [50 mM HEPES-NaOH (pH 7.5), 4 mM PEP, $200 \mathrm{mM} \mathrm{KCl,} 10 \mathrm{mM} \mathrm{MgCl} 2$, and $1.2 \mathrm{U}$ pyruvate kinase] was added in, incubate in $30{ }^{\circ} \mathrm{C}$ water bath to react $20 \mathrm{~min}$, the reaction was stopped at boiling water bath for $5 \mathrm{~min}$, centrifuged $5 \mathrm{~min}$ at $10000 \mathrm{~g}, 330 \mu \mathrm{L}$ supernatant was added into $237 \mu \mathrm{L}$ reaction buffer C[50 mmol/L HEPES-NaOH (pH 7.5), 10 $\mathrm{mmol} / \mathrm{L}$ glucose, $20 \mathrm{mmol} / \mathrm{L} \mathrm{MgCl}_{2}, 2 \mathrm{mmol} / \mathrm{L}$ NADP, 1.4 unit hexokinase, 0.35 unit glucose 6-phosphate dehydrogenase], mixed and incubated in $30{ }^{\circ} \mathrm{C}$ water bath to react 10 min, colorimetric analysis at $340 \mathrm{~nm}$. The NADH content was calculated by the molar extinction coefficient (6220) of NADH at 340nm.

\subsection{The Determination of Enzyme Activity of Cassava Root Tuber SBE}

The method of Li et al. (1997) was followed. About $3 \mathrm{~g}$ cassava tuber powder was ground with $2 \mathrm{~mL} 0.05 \mathrm{~mol} / \mathrm{L}$ citrate buffer ( $\mathrm{pH} \mathrm{7.0)}$ in ice-cold mortar, the mortar was washed twice with $2 \mathrm{~mL} 0.05 \mathrm{~mol} / \mathrm{L}$ citrate buffer, the buffer was collected together, centrifuged $20 \mathrm{~min}$ at $18000 \mathrm{rpm}$, the supernatant was used as crude enzyme. $1 \mathrm{~mL}$ above enzyme solution, $1 \mathrm{~mL}$ $0.2 \mathrm{~mol} / \mathrm{L}$ citrate buffer $(\mathrm{pH} 7.0), 0.5 \mathrm{~mL} 0.1 \mathrm{~mol} / \mathrm{L}$ EDTA (with shaking, to inactivate $\alpha$-amylase) and $0.1 \mathrm{~mL} 7.5 \mathrm{~g} / \mathrm{L}$ soluble starch were mixed together, incubated in $37{ }^{\circ} \mathrm{C}$ water bath to react $40 \mathrm{~min}$, the reaction was stopped by adding $4 \mathrm{~mL} 10 \%$ trichloroacetic acid, centrifuged $8 \mathrm{~min}$ at $3000 \mathrm{rpm}, 0.3 \mathrm{~mL}$ iodine solution was added into the supernatant, the OD660nm was measured after $10 \mathrm{~min}$. Use the $0 \mathrm{~min}$ as the control, enzyme activity is 
represented by the decreased percentage of OD 660, so $1 \mathrm{U}$ is OD 660 decrease $1 \%$ per min.

\subsection{The Determination of Cassava Root Tuber Starch}

The method of Jin et al. (2009) was followed. The amylose and amylopectin content of cassava root tuber were determined by dual-wavelength spectrophotometry, respectively. Then total starch content was calculated by adding amylose and amylopectin content together.

\subsection{Data Processing}

MS Excel was used to calculate the data for plotting; Software DPS 7.05 was used for statistical analysis and Duncan's new multiple range test was used for analysis. All data in the following figures are the mean of three replications. The small letters at the top of each column indicate the significant difference at $P<0.05$.

\section{Results and Discussion}

3.1 The Time Course of Cassava Leaf SuS Synthesis Direction and Decomposing Direction Activity

The carbohydrate synthesized from cassava leaf photosynthesis is the source of cassava tuber starch. Cassava leaf SuS plays an important role in the distribution of the photosynthesized carbohydrate (Zheng et al., 2011), thereby affects the cassava tuber starch accumulation. The cassava leaf SuS synthesis and decomposing direction activities were determined during the growth period (Figure 1 and 2). For the cassava leaf SuS synthesis direction activity, all the four cassava cultivars' enzyme activities were highest at August among the growth period determined, then decreased gradually during the succeeding months. For the cassava leaf SuS decomposing direction activity, it decreased initially then increased gradually to form a parabolic curve during the growth period. Taking together, the function of SuS is for the sucrose synthesis only in August, however for sucrose decomposition for other months. Poovaiah et al (2015) increased the biomass of switchgrass through overexpression of switchgrass sucrose synthase gene PvSUS1. This suggested that cassava starch might be increased through similar approach.

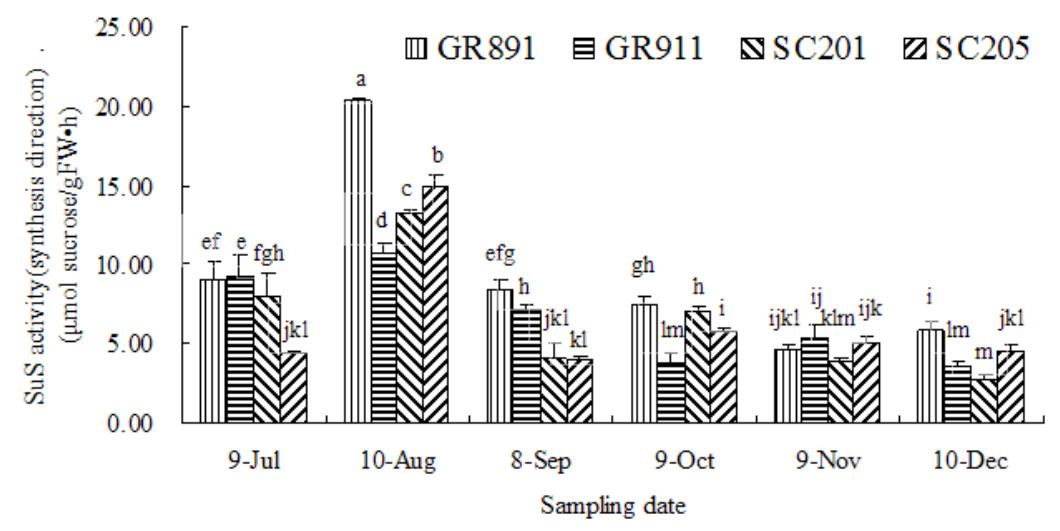

Figure 1. The time course of cassava leaf SuS activity of synthesis direction 


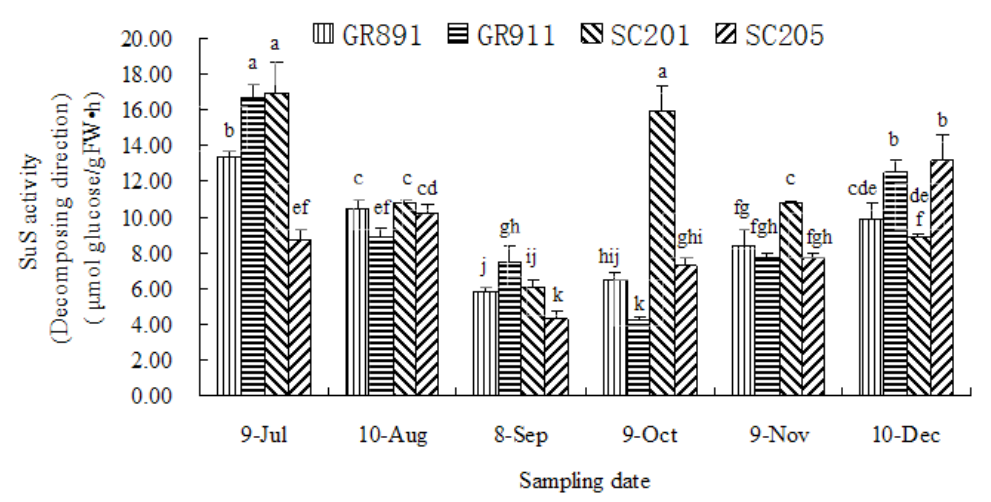

Figure 2. The time course of cassava leaf SuS activity of decomposing direction

\subsection{The Time Course of Cassava Leaf SPS Enzyme Activity}

SPS is another enzyme for the synthesis of sucrose. As known sucrose is the carbohydrate transported from source to sink. The higher SPS activity will favor the synthesis of sucrose, thus promote the carbohydrate to be transferred from source (cassava leaves) to sink (cassava tuber) for starch biosynthesis (Lutfiyya et al., 2007). All the four cassava cultivars' SPS activities were highest at August among the growth period; this showed that August is much more important than other months for tuber starch accumulation (Figure 3). For the high starch content cultivar GR891, the SPS activities were almost highest among the four cultivars during the growth period.

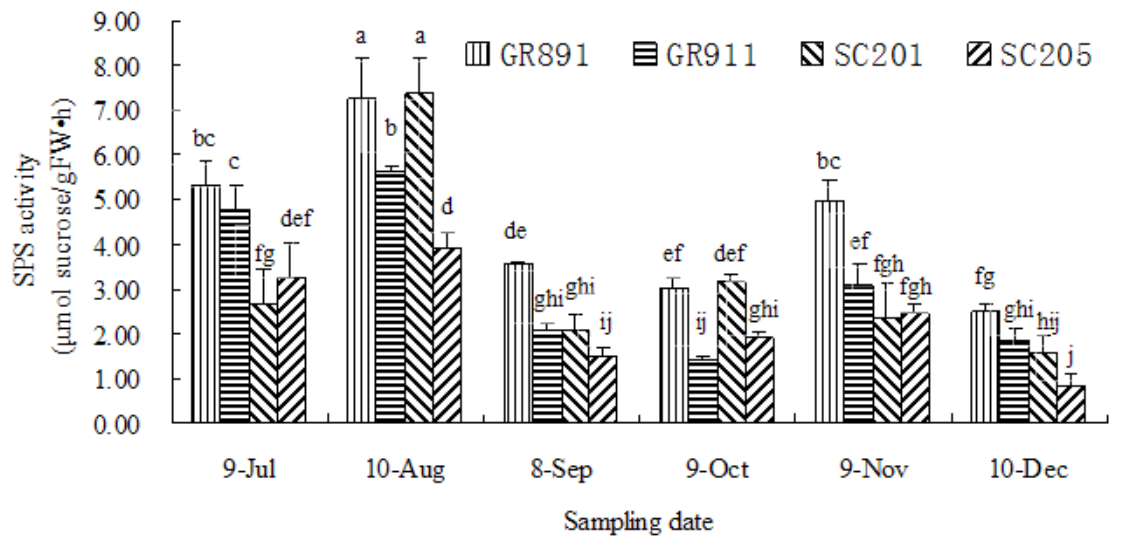

Figure 3. The time course of cassava leaf SPS activity

\subsection{The Time Course of Cassava Root Tuber AGPase Enzyme Activity}

As well known, the reaction catalyzed by AGPase is the key and rate-limiting step of starch biosynthesis (Huang et al., 2011). The rate of starch accumulation has direct relationship to its enzyme activity. The enzyme activity of AGPase in August, September and October were all higher than other months (Figure 4), it indicated that these three months played important role for the cassava root starch production. The AGPase activity of cultivar GR891 was the highest among the four cultivars determined. These results were consistent with that the starch content of GR891 was also the highest among the four cultivars.

Tan et al. (2009) studied the transcription and enzyme activity of AGPase during the formation of wheat seed by using fluorescent quantitative PCR and enzyme activity assay 


\section{MInstitute Macrothink $_{\text {Int }}$}

method. It was found that they all formed a single peak curve. This result was consistent with the cassava root tuber AGPase activity determined in this study (Figure 4). This indicated that there was a starch formation peak during the accumulation of starch. Kang et al (2013) increased the starch content and grain weight of common wheat through overexpression of the cytosolic AGPase large subunit gene. This study hinted that AGPase is important in starch biosynthesis, and this approach could be utilized for increasing cassava starch accumulation through molecular breeding.

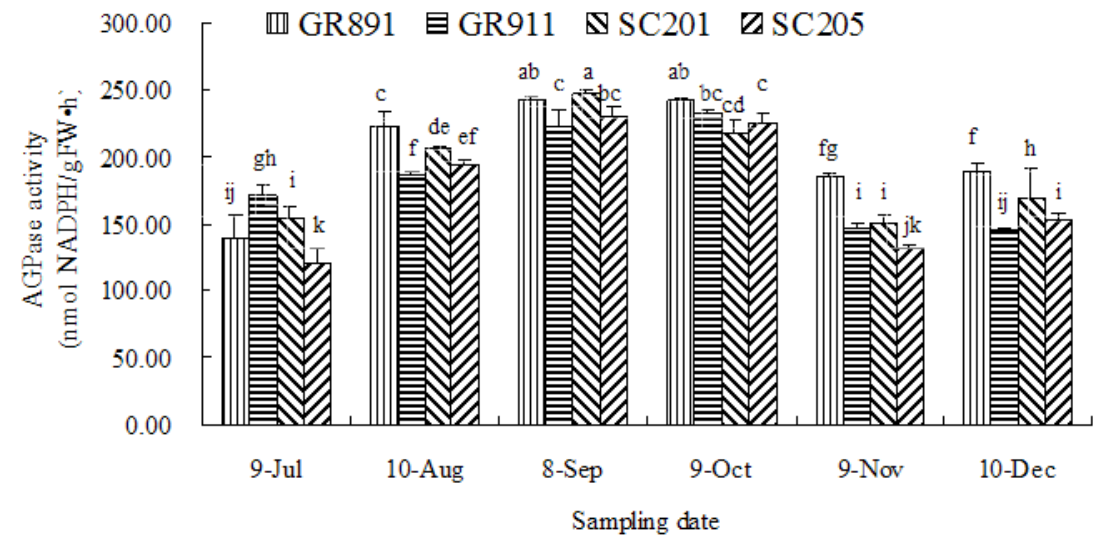

Figure 4. The time course of AGPase activity of cassava root tuber

\subsection{The Time Course of Cassava Root Tuber SSS Enzyme Activity}

It was known that cassava root tuber SSS mainly involved in the biosynthesis of amylopectin, so its activity determines the amylopectin content (Zhang et al., 2008). The SSS activities of four cultivars were all decreased gradually along the growth period (Figure 5). It is postulated from this result that the amylopectin biosynthesis rate is higher at early stage than late stage.

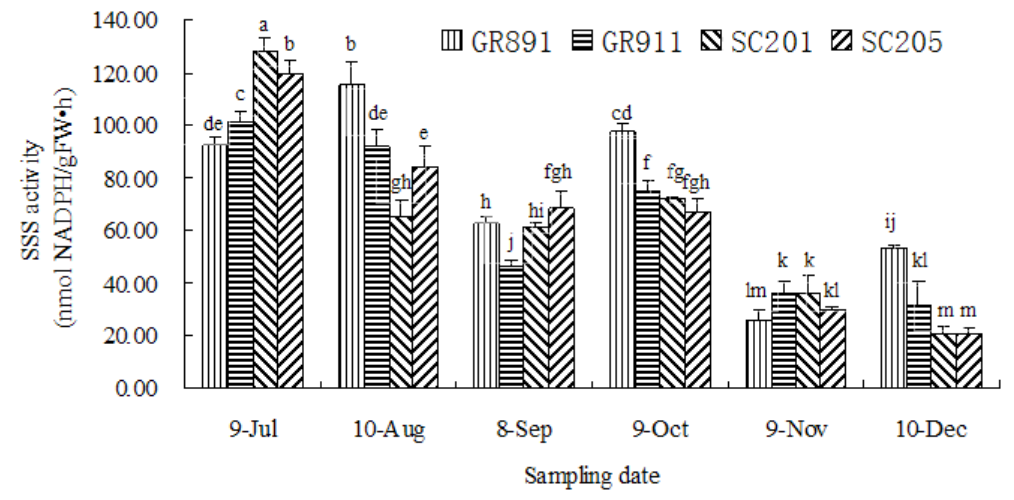

Figure 5. The time course of SSS activity of cassava root tuber

\subsection{The Time Course of Cassava Root Tuber SBE Enzyme Activity}

Cassava root tuber SBE is also involved in the biosynthesis of amylopectin, however it is mainly to modify the fine structure of amylopectin (Xia et al., 2011). Although the cassava root tuber SBE activity of four cultivars oscillated during the growth period, the range was not too much (Figure 6). Taking the amylopectin content of fresh weight continually increasing into consideration (Figure 8), it is postulated that SBE might not play an important role in the formation of amylopectin, but to its fine structure modification. 


\section{I Macrothink}

Journal of Agricultural Studies

ISSN 2166-0379

2017, Vol. 5, No. 1

SSS is an important enzyme for starch biosynthesis, especially for amylopectin. SBE can further modify the structure of amylopectin. The enzyme activity change style of cassava root SSS (Figure 5) and SBE (Figure 6) were not conformed well to those of maize (Zuo et al., 2011) and wheat (Wang and Wang, 2004). The reason of this inconsistence is not known so far and worth to study further.

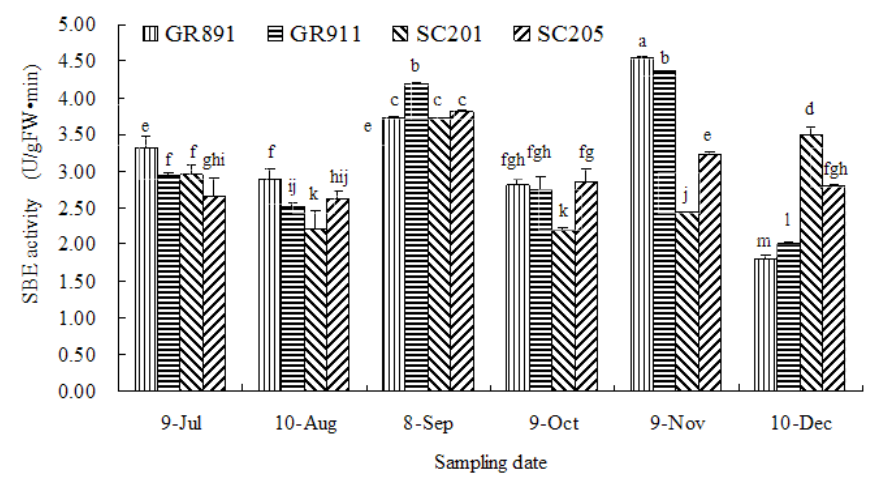

Figure 6. The time course of SBE activity of cassava root tuber

\subsection{The Time Course of Cassava Root Tuber Starch}

The amylose and amylopectin content of cassava root tuber were determined by dual wavelength spectrophotometry, respectively (Figure 7 and 8), and the total starch content of fresh weight was calculated (Figure 9). The amylose, amylopectin and total starch content of fresh cassava root tuber of four cultivars were continually increased along with the growth period (Figure 7, 8, 9). GR891 and SC205 were two cultivars which were known as high-starch content and planted widely in Guangxi. From our results, the amylose, amylopectin and total starch content of GR891 and SC205 were actually higher than those of GR911 and SC201, and GR891 was the highest among the four cultivars determined.

The amylose, amylopectin and total starch content of fresh cassava root tuber were all increased gradually along with the growth period (Figure 7, 8, 9). The correlation between the starch accumulation and the determined enzyme activities is not very well. As we know, the starch biosynthesis is very complex process, and it is influenced by many biofactors (Martin and Smith, 1995). Although, SuS, SPS, AGPase, SSS and SBE are important enzymes for starch biosynthesis, they are only part of the whole starch biosynthesis net.

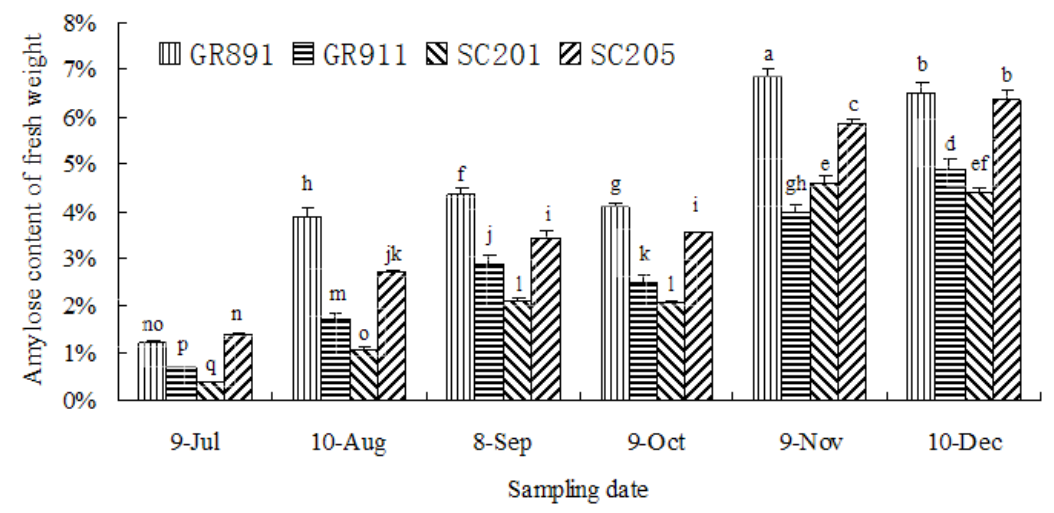

Figure 7. The time course of amylose content of fresh cassava root tuber 


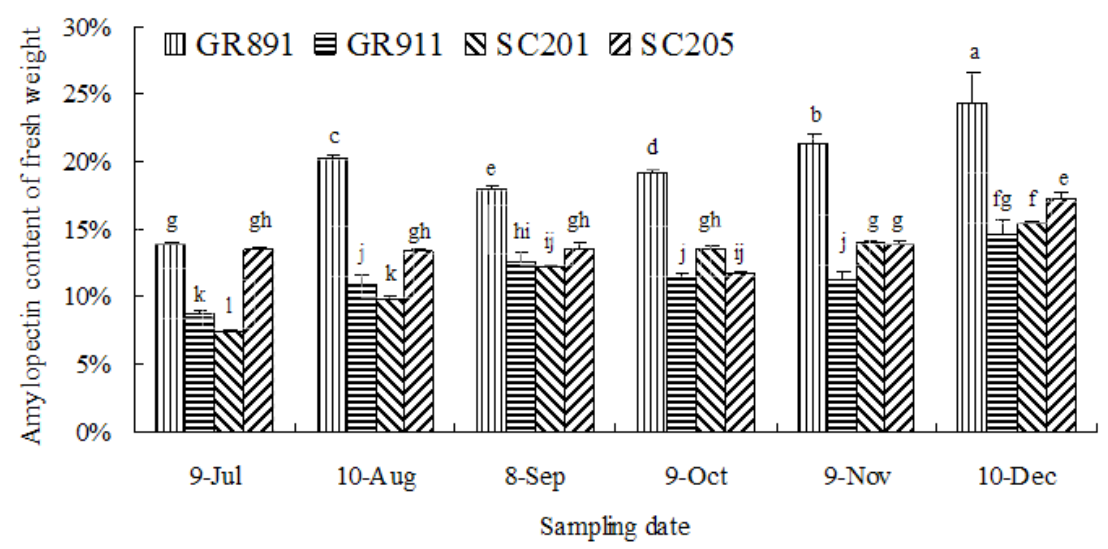

Figure 8 . The time course of amylopectin content of fresh cassava root tuber

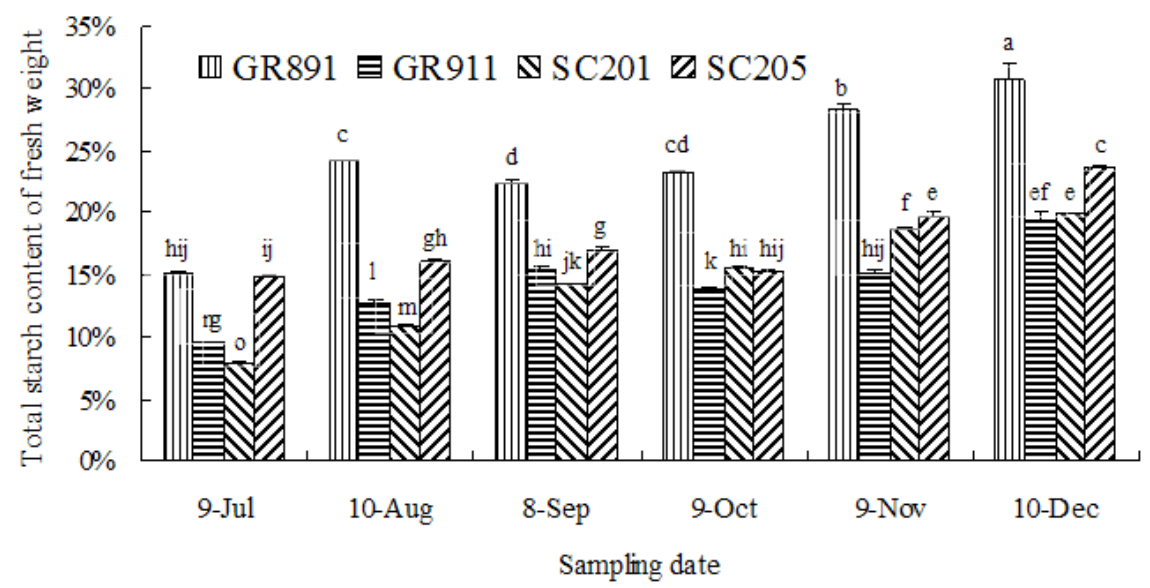

Figure 9. The time course of total starch content of fresh cassava root tuber

\section{Conclusion}

The time course of four cassava cultivars' root tuber starch content, and starch biosynthesis related enzymes of cassava leaves and root tuber were determined during their growth period. The trends of SuS decomposing direction, SuS synthesis direction, SPS, AGPase, SSS, SBE activities were different from each other; however the amylose, amylopectin and total starch content of cassava root tuber gradually increased along with the growth period. And the amylose, amylopectin and total starch content of GR891 and SC205, especially GR891 was higher than others. This result is consistent with that GR891 and SC205 are well-known high starch content cultivars. The changing trends of cassava root tuber starch accumulation and its related biosynthesis enzymes were becoming clear through this experiment.

\section{Acknowledgments}

This work was supported by Guangxi scientific research and technological development foundation (09203-03).

\section{References}

Balagopalan, C. (2002). Cassava utilization in food, feed and industry. In Cassava Biology, Production and Utilization. Oxford, New York: CABI Publishing, pp: 301-318. https://doi.org/10.1079/9780851995243.0301

Carvalho, L.J.C.B., de Souza, C.R.B., de Mattos Cascardo, J.C., Bloch, C., \& Campos, L. 
(2004). Identification and characterization of a novel cassava (Manihot esculenta Crantz) clone with high free sugar content and novel starch. Plant Molecular Biology, 56, 643-659. https://doi.org/10.1007/s11103-004-4873-9

Cook, R., \& Cock, J. (1989). Cassava crops up again. New Scientist, 122, 63-68.

Huang, B.Q., Chen, J., Zhang, J.J., Liu, H.M., Tian, M.L., Gu, Y., Hu, Y.F., Li, Y.P., Liu, Y.H., \& Huang, Y.B. (2011). Characterization of ADP-glucose pyrophosphorylase encoding genes in source and sink organs of maize. Plant Molecular Biology Reporter, 29, 563-572. https://doi.org/10.1007/s11105-010-0262-5

Ihemere, U., Arias-Garzon, D., Lawrence, S., \& Sayre, R. (2006). Genetic modification of cassava for enhanced starch production. Plant Biotechnology Journal, 4, 453-465. https://doi.org/10.1111/j.1467-7652.2006.00195.x

Jin, Y. H., Zhang, K. L., Zhang, X. C., \& Du, J. H. (2009). Determination of amylose and amylopectin in wheat and wheat malt by dual-wavelength spectrophotometry. Journal of the Chinese Cereals and Oils Association, 24, 137-140.

Kang, G. Z., Liu, G. Q., Peng, X. Q., Wei, L. T., Wang, C. Y., Zhu, Y. J., Ma, Y., Jiang, Y. M., $\&$ Guo, T. C. (2013). Increasing the starch content and grain weight of common wheat by overexpression of the cytosolic AGPase large subunit gene. Plant Physiology and Biochemistry, 73, 93-98. https://doi.org/10.1016/j.plaphy.2013.09.003

Li, T. G., Shen, B., Cheng, N., \& Luo, Y.K. (1997). Effect of Q-enzyme on the chalkiness formation of rice grain. Acta Agronomica Sinica, 23, 338-344.

Lutfiyya, L. L., Xu, N. F., D’Ordine, R. L., Morrell, J. A., Miller, P. W., \& Duff, S. M. G. (2007). Phylogenetic and expression analysis of sucrose phosphate synthase isozymes in plants. Journal of Plant Physiology, 164, 923-933.

https://doi.org/10.1016/j.jplph.2006.04.014

Martin, C., \& Smith, A. M. (1995). Starch Biosynthesis. The Plant Cell, 7, 971-985. https://doi.org/10.1105/tpc.7.7.971

Nakamura, Y., Yuki, K., Park, S. Y., \& Ohya, T. (1989). Carbohydrate metabolism in the developing endosperm of rice grains. Plant Cell Physiology, 30, 833-839.

Osei, G., Arthur, R., Afrane, G., \& Agyemang, E. O. (2013). Potential feedstocks for bioethanol production as a substitute for gasoline in Ghana. Renewable Energy, 55, 12-17. https://doi.org/10.1016/j.renene.2012.12.012

OU-Lee, T. M., \& Setter, T. L. (1985). Enzyme activities of starch and sucrose pathways and growth of apical and basal maize kernels. Plant Physiology, 79, 848-851. https://doi.org/10.1104/pp.79.3.848

Pan, H., Luo, Y. C., Zheng, H., Yu, B. H., Lu, S. Q., \& Li, J. (2014). Effects of different compound fertilizers on qualitycharacteristics and yield of cassava. Journal of Southern Agriculture, 44, 2023-2026.

Pimentel, T. A. P. F., Durães, J. A., Drummond, A. L., Schlemmer, D., Falcão, R., \& Sales, 
M. J. A. (2007). Preparation and characterization of blends of recycled polystyrene with cassava starch. Journal of Materials Science, 42, 7530-7536. https://doi.org/10.1007/s10853-007-1622-X

Poovaiah, C. R., Mazarei, M., Decker, S. R., Turner, G. B., Sykes, R. W., Davis, M. F., \& Stewart, C. J. (2015). Transgenic switchgrass (Panicum virgatum L.) biomass is increased by overexpression of switchgrass sucrose synthase (PvSUS1). Biotechnology Journal, 10, 552-563. https://doi.org/10.1002/biot.201400499

Tan, C. X., Guo, J., Chen, J., Feng, C. N., Guo, W. S., Zhu, X. K., Li, C. Y., \& Peng, Y. X. (2009). Study on gene expression involved in starch synthesis and activities of enzymes in wheat grain. Jounal of Triticeae Crops, 29, 24-30.

Wang, F., \& Wang, X. Z. (2004). Study on the dynamic changes of starch synthesis and their related enzymes in wheat. Journal of Triticeae Crops, 24, 57-60.

Xia, H., Yandeau-Nelson, M., Thompson, D. B., \& Guiltinan, M. J. (2011). Deficiency of maize starch-branching enzyme I results in altered starch fine structure, decreased digestibility and reduced coleoptile growth during germination. BMC Plant Biology, 11, 95-108. https://doi.org/10.1186/1471-2229-11-95

Yu, J. X. (1999). The determination of sucrose synthase and sucrose phosphate synthase activities. In The experimental guide of modern plant physiology, edited by Fan SQ and Liang SW, published by Chinese scientific publication corporation, pp126.

Zhang, X. L., Szydlowski, N., Delvallé, D., D'Hulst, C., James, M. G., \& Myers, A. M. (2008). Overlapping functions of the starch synthases SSII and SSIII in amylopectin biosynthesis in Arabidopsis. BMC Plant Biology, 8, 96-114.

https://doi.org/10.1186/1471-2229-8-96

Zhao, Y., Wei, Z. M., \& Ma, F. M. (2003). Influence of ammoniacal nitrogen on sucrose synthase and sucrose phosphate synthase in sugar beet. Sugar Crops of China, 1-5.

Zheng, Y., Anderson, S., Zhang, Y. F., \& Garavito, R. M. (2011). The structure of sucrose synthase-1 from Arabidopsis thaliana and its functional implications. Journal of Biological Chemistry, 86, 36108-36118. https://doi.org/10.1074/jbc.M111.275974

Zuo, Z. P., Tian, F. L., Jiang, P., Wang, J., Ma, D. C., Ma, Q., Li, D., Sun, Q. Q., \& Dong, S. T. (2011). Comparison of kernel starch accumulation and related enzyme activities among six maize cultivars of different yield types. Acta Agronomica Sinica, 37, 529-536. https://doi.org/10.3724/SP.J.1006.2011.00529

\section{Copyright Disclaimer}

Copyright for this article is retained by the author(s), with first publication rights granted to the journal.

This is an open-access article distributed under the terms and conditions of the Creative Commons Attribution license (http://creativecommons.org/licenses/by/4.0/). 